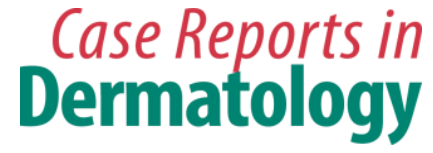

Case Rep Dermatol 2018;10:138-144

DOI: $10.1159 / 000488900$

Published online: May 24, 2018

C) 2018 The Author(s)

Published by S. Karger AG, Basel

www.karger.com/cde

This article is licensed under the Creative Commons Attribution-NonCommercial 4.0 International License (CC BY-NC) (http://www.karger.com/Services/OpenAccessLicense) Usage and distribution for commercial purposes requires written permission.

\title{
Nevus Lipomatosis Cutaneous Superficialis: A Single-Center Case Series of 5 Patients
}

\author{
Homaid Alotaibi ${ }^{a} \quad$ Fahad Alsaif $^{\mathrm{a}}$ Azhar Alali $^{\mathrm{a}}$ Mohammed Almashali $^{\mathrm{b}}$ \\ Dana Al-Dabeeb ${ }^{a} \quad$ Abdul-Aziz Altaweel $^{c}$ \\ aDermatology Department, College of Medicine, King Saud University, Riyadh, Saudi \\ Arabia; 'Dermatology Department, College of Medicine, Al-Imam Mohammad Ibn Saud \\ Islamic University, Riyadh, Saudi Arabia; 'King Saud bin Abdul-Aziz University for Health \\ Sciences, Riyadh, Saudi Arabia
}

\section{Keywords}

Nevus lipomatosis cutaneous superficialis · Skin tumor · Histopathology

\begin{abstract}
Background: Nevus lipomatosis cutaneous superficialis (NLCS) is a rare hamartoma of mature adipose tissue characterized by solitary or multiple, soft, skin-colored or yellowish lobules that may coalesce to give rise to plaques with a cerebriform surface. There are two clinical types: (1) multiple lesions that are usually presented in a segmental distribution and (2) a solitary papule or nodule. Aim and Objective: To study the clinical and histopathological features of 5 Saudi patients with NLCS. Method: A retrospective analysis of clinical data and histopathological findings of 5 cases of NLCS in King Khalid University Hospital between January 2011 and November 2016. Demographic and clinical data were obtained from the clinical case files. Slides and tissue blocks were retrieved. H\&E- and EVG-stained slides were studied in all cases. Results: We identified 5 patients with NLCS, of whom 4 were female. The average age at diagnosis was 36 years. The mean duration of the lesion was 4.4 years. The most common location was the lower part of the body. Most of the cases were diagnosed as skin papilloma before skin biopsy. Surgical excision was effective and no recurrence was observed. Conclusion: This is the first study about this rare type of skin tumor in Saudi Arabia and highlights the need for awareness of this clinical condition among dermatologists.
\end{abstract}

(C) 2018 The Author(s)

Published by S. Karger AG, Basel 


\section{Introduction}

Nevus lipomatosis cutaneous superficialis (NLCS) is a rare benign idiopathic hamartomatous anomaly of the skin. It was firstly discovered as pedunculated lipofibroma by Hoffmann and Zurhelle in 1921 [1] and characterized histologically by ectopic mature adipose tissue within the reticular dermis without connection to underlying subcutaneous fat $[2,3]$. There is no gender prevalence or hereditary predisposition of this disease [3]. Clinically, there are two forms: the classical type (or multiple form) is the most common form and usually occurs over the pelvic-girdle area and manifests as groups of multiple, soft, nontender, pedunculated, cerebriform, yellowish or skin-colored papules or nodules which may coalesce to gather and form large plaques; these lesions usually present at birth or within the first 3 decades of life $[3,4]$. The second type is the solitary form (rare form) which usually presents as a solitary dome-shaped sessile papule or nodule, typically with late onset and no specific distribution $[5,6]$.

We report here 5 cases of NLCS (initially misdiagnosed as skin papilloma or skin tags) in order to increase awareness about this rare disease and to emphasize the importance of its histopathology.

\section{Methods}

We retrospectively reviewed the records and histopathology of 5 patients with NLCS. They were seen at general dermatology clinics at King Khalid University Hospital in Riyadh from 2011 to 2016. We collected and analyzed the biopsies of these 5 patients. The following clinical characteristics were recorded for analysis: age, gender, clinical features, histopathology, and treatment. All histopathology reports were reviewed by a dermatopathologist.

\section{Case Presentation}

A systematic multidisciplinary clinical investigation and familial enquiry were performed for each patient.

\section{Case Report 1}

A 37-year-old female patient, a known case of vitiligo (on mometasone cream and tacrolimus ointment $0.01 \%$ ), complained of a single asymptomatic colored lesion for 4 years. Physical examination showed the single form of NLCS measuring $2 \times 1.2 \mathrm{~cm}$ on the lower part of the left leg. Surgical excision of the lesion was performed.

Case Report 2

A 58-year-old female patient known to have diabetes (on metformin) presented with a history of an asymptomatic single lesion, which had been progressing in size over 10 years. Physical examination showed NLCS presenting like grayish pedunculated plaques measuring $2.7 \times 2.3 \mathrm{~cm}$ over the lower abdomen. 
Case Report 3

A 30-year-old healthy female presented with an asymptomatic lesion over the medial aspect of the right thigh, which was gradually progressive over the past 5 years. Physical examination showed a skin-colored pedunculated nodule measuring $3 \times 2 \mathrm{~cm}$. The clinical diagnosis was skin tag and the treatment was surgical excision.

\section{Case Report 4}

A 48-year-old female, a known case of hypothyroidism (on L-thyroxine) and hypertension (on Concord) presented with a single skin lesion. Physical examination showed a polypoid nodule measuring $2 \times 1.5 \mathrm{~cm}$ over the perianal area, which had been there for 3 years. Clinical diagnosis was skin tag and surgical removal was performed.

\section{Case Report 5}

A 12-year-old boy presented with multiple papules and nodules over the sacral area which had been there since birth. Clinical diagnosis was NLCS.

\section{Histopathology}

All cases showed the same features which revealed a polypoid skin lesion, and highpower view exhibited benign adipose tissue in the dermis.

\section{Results}

Five cases of NLCS were identified between 2011 and 2016. The clinical details are summarized in Table 1. Four of the five NLCS patients were female. The mean age at diagnosis was 36 years and the mean duration of the lesion was 4.4 years. Three cases were initially diagnosed clinically as skin papillomas or skin tags. Only 1 patient had the lesion since birth while the other 4 patients had acquired the lesion through the second and third decades. Clinical presentation was that of the solitary form in 4 patients and the classical form in 1 patient (Fig. 1). There were no other cutaneous anomalies and no family history of the same disease. Histopathological features were typical of NLCS showing ectopic mature adipose tissue in the dermis (Fig. 2). Four patients underwent surgical excision of the lesion.

\section{Discussion}

NLCS, first described by Hoffman and Zurhelle in 1921, is a rare benign idiopathic hamartomatous anomaly of the skin characterized by a collection of mature adipocytes ectopically situated in the dermis $[1,2,6]$. NLCS is usually present at birth, but can appear later in life; there is neither sex predilection nor familial trend in this disorder [3-6]. In our study 4 of the 5 cases were female, and the onset of this hamartomatous disorder was late (second and third decade) due to the fact that most of our cases were of the solitary form.

Clinically, there are two forms. The classical type, which is the commonest type, consists of multiple flesh-colored or yellowish sessile lesions with a tendency to coalesce into plaques with a smooth or cerebriform surface with a linear, zosteriform, or segmental distribution. 
The lessons have a predilection for the lower trunk, especially the pelvic girdle and gluteal, sacral, and lumbar regions $[3,4,6]$.The second clinical pattern of NLCS is a solitary papule or nodule which usually has late onset and presents clinically as a solitary, skin-colored, domed papule or nodule mimicking a skin tag. There is no specific distribution for the solitary form, which has been reported on the arms, knees, axillae, ears, nose, calf, clitoris, and scalp [3, 4, 6-9]. Only 1 patient in our study presented with the classical form and, interestingly, all the solitary lesions were over the lower part of the body.

NLCS have an asymptomatic and static course, although some lessons may have unusual growth or morphology such as giant NLCS [7], comedo-like plug [10], foul-smelling discharge [10], and ulcerated lesions after external trauma or ischemia [11]. On the other hand, rare coexistent anomalies have been reported with NLCS such as café-au-lait macules and scattered leukoderma [12], angiokeratoma of Fordyce, and hemangioma [13]. Recurrence has rarely been reported [14]. There are no systemic abnormalities or malignant transformation. In our study, no associated skin abnormalities were present and no recurrence was observed up to the time of this study report.

The pathogenesis of NLCS is not known, but the ectopic adipocytes may originate from precursor cells from the dermal vessels or from pericytes, as in fetal lipogenesis $[6,8]$.The classical histopathology showed dispersed or grouped lobules of adipose tissue, composed of well-differentiated adipocytes which intermingled with collagen bundles, with perivascular infiltration of the dermis and subcutis with chronic inflammatory cells [6]. Other rare histopathological features have been reported such as increased basal pigmentation and focal elongation of rete pegs [8], reduced adnexal structures [8], and abnormal folliculosebaceous structures such as sebaceous trichofolliculoma, folliculosebaceous cystic hamartoma, and dermoid cysts $[15,16]$. All our cases showed mature adipocytes in the dermis with normal collagen bundles between these adipocytes.

Many clinical dermatoses may have a similar clinical presentation such as papillomas (skin tags), plexiform neurofibroma, nevus sebaceous, connective tissue nevus, vascular malformation, and lipoblastomatosis. Four cases in our study were initially diagnosed as skin tags and we documented the diagnosis only through histopathology. Treatment is not necessary unless for cosmetic reasons and the treatment of choice is surgical excision [17], but cryotherapy was used with partial improvement [13].

\section{Statement of Ethics}

Approval for research conduction and data collection was obtained from the King Abdullah International Medical Research Center Ethics and Scientific Committee. Also, informed consent was obtained from each individual who participated in the study.

\section{Disclosure Statement}

The authors have no conflicts of interest to disclose. 


\section{Funding Sources}

This case series report is one of the academic activities usually run by dermatologists in the Saudi Board of Dermatology and there was no funding for the study.

\section{References}

1 Hoffman E, Zurhelle E. Uber einen Naevus lipomatodes cutaneous superficialis der linken Gilutaalgegend. Arch Derm Syphilol. 1921;130(1):327-33.

2 Abel R, Dougherty JW. Naevus lipomatosus cutaneous superficialis (Hoffmann-Zurhelle). Arch Dermatol. 1962;85(4):524-6.

3 Goucha S, Khaled A, Zéglaoui F, Rammeh S, Zermani R, Fazaa B. Nevus lipomatosus cutaneous superficialis: report of eight cases. Dermatol Ther (Heidelb). 2011 Dec;1(2):25-30.

4 Triki S, Mekni A, Haouet S, Mokni M, Kchir N, Ben Osman Dhahri A et al. [Nevus lipomatosus cutaneous superficialis: a clinico-pathological study of 13 cases]. Tunis Med. 2006 Dec;84(12):800-2. French.

5 Dotz W, Prioleau PG. Nevus lipomatosus cutaneous superficialis. Arch Dermatol. 1984;120(3):376-9.

6 Jones EW, Marks R, Pongsehirun D. Naevus superficialis lipomatosus. A clinicopathological report of twenty cases. Br J Dermatol. 1975 Aug;93(2):121-33.

7 Knuttel R, Silver EA. A cerebriform mass on the right buttock. Dermatol Surg. 2003 Jul;29(7):780-1.

8 Buch AC, Panicker NK, Karve PP. Solitary nevus lipomatosus cutaneous superficialis. J Postgrad Med. 2005 Jan-Mar;51(1):47-8.

9 Ioannidou DJ, Stefanidou MP, Panayiotides JG, Tosca AD. Nevus lipomatosus cutaneous superficialis (Hoffmann-Zurhelle) with localized scleroderma like appearance. Int J Dermatol. 2001 Jan;40(1):54-7.

10 Ghosh SK, Bandyopadhyay D, Jamadar NS. Nevus lipomatosus cutaneous superficialis: an unusual presentation. Dermatol Online J. 2010 Jul;16(7):12.

11 Dhar S, Kumar B, Kaur I. Naevus lipomatosus superficialis of Hoffman and Zurhelle. Indian J Dermatol Venereol Leprol. 1994;60:39-40.

12 Khandpur S, Nagpal SA, Chandra S, Sharma VK, Kaushal S, Safaya R. Giant nevus lipomatosus cutaneous superficialis. Indian J Dermatol Venereol Leprol. 2009 Jul-Aug;75(4):407-8.

13 Al-Mutairi N, Joshi A, Nour-Eldin O. Naevus lipomatosus cutaneous superficialis of Hoffmann-Zurhelle with angiokeratoma of Fordyce. Acta Derm Venereol. 2006;86(1):92-3.

14 Dhamija A, Meherda A, D’Souza P, Meena RS. Nevus lipomatosus cutaneous superficialis: an unusual presentation. Indian Dermatol Online J. 2012 Sep;3(3):196-8.

15 Brasanac D, Boricic I. Giant nevus lipomatosus superficialis with multiple folliculosebaceous cystic hamartomas and dermoid cysts. J Eur Acad Dermatol Venereol. 2005 Jan;19(1):84-6.

16 Bancalari E, Martinez-Sanchez D, Tardio JC. Nevus lipomatosus superficialis with a folliculosebaceous component: report of 2 cases. Patholog Res Int. 2011 Apr;2011:105973.

17 Lane JE, Clark E, Marzec T. Nevus lipomatosus cutaneus superficialis. Pediatr Dermatol. 2003 JulAug;20(4):313-4. 


\section{Case Reports in Dermatology}

Case Rep Dermatol 2018;10:138-144 www.karger.com/cde

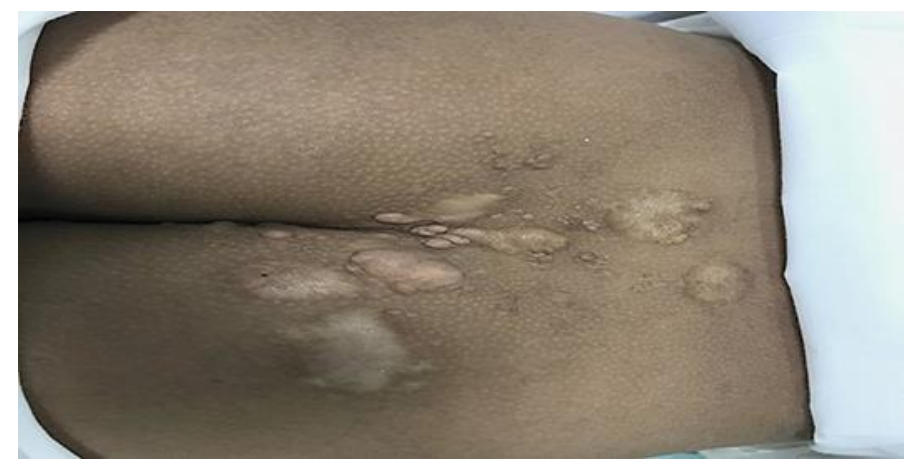

Fig. 1. A 12-year-old boy presented with multiple papules and nodules over the sacral area which had been there since birth.

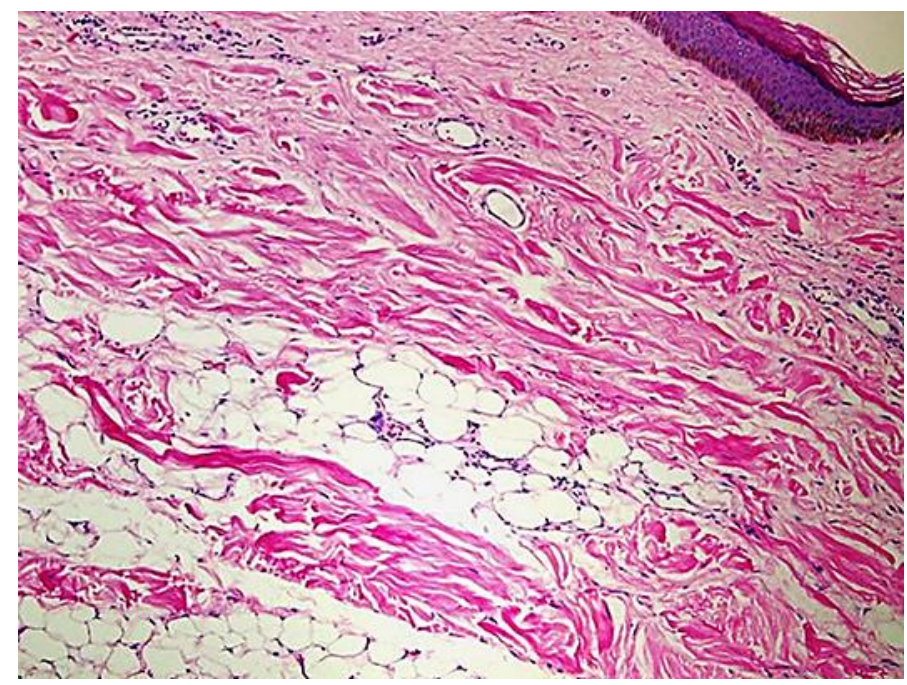

Fig. 2. Low-power view of skin biopsy stained by H\&E shows mature adipocytes in between the normal collagen bundles. 
Table 1. Detailed history of the 5 cases

\begin{tabular}{|c|c|c|c|c|c|c|}
\hline $\begin{array}{l}\text { Case } \\
\text { No. }\end{array}$ & Sex & $\begin{array}{l}\text { Age, } \\
\text { years }\end{array}$ & Duration & Location & Clinical features & Treatment \\
\hline 1 & female & 37 & 4 years & left lower leg & $\begin{array}{l}\text { single skin-colored lobulated } \\
\text { nodule measuring } 2 \times 1.2 \mathrm{~cm}\end{array}$ & $\begin{array}{l}\text { surgical } \\
\text { excision }\end{array}$ \\
\hline 2 & female & 58 & 10 years & lower abdomen & $\begin{array}{l}\text { skin-colored to grayish peduncu- } \\
\text { lated plaques measuring } 2.7 \times \\
2.3 \mathrm{~cm}\end{array}$ & $\begin{array}{l}\text { surgical } \\
\text { excision }\end{array}$ \\
\hline 3 & female & 30 & 5 years & $\begin{array}{l}\text { medial aspect of } \\
\text { the right thigh }\end{array}$ & $\begin{array}{l}\text { skin-colored pedunculated nod- } \\
\text { ule measuring } 3 \times 2 \mathrm{~cm}\end{array}$ & $\begin{array}{l}\text { surgical } \\
\text { excision }\end{array}$ \\
\hline 4 & female & 48 & 3 years & perianal area & $\begin{array}{l}\text { giant polypoid nodule measuring } \\
2 \times 1.5 \mathrm{~cm}\end{array}$ & $\begin{array}{l}\text { surgical } \\
\text { excision }\end{array}$ \\
\hline 5 & male & 12 & $\begin{array}{l}\text { since } \\
\text { birth }\end{array}$ & sacral area & $\begin{array}{l}\text { multiple soft skin-colored pap- } \\
\text { ules and nodules }\end{array}$ & observation \\
\hline
\end{tabular}

